\title{
State of the art in the treatment of systemic vasculitides
}

\author{
Raashid Ahmed Luqmani * \\ NDORMS, Rheumatology Department, Nuffield Orthopaedic Centre, University of Oxford, Oxford, UK
}

\section{Edited by:}

Giuseppe Alvise Ramirez, Università Vita-Salute San Raffaele, Italy

\section{Reviewed by:}

Fulvio D'Acquisto, Queen Mary University of London, UK

Jaewoo Hong, National Institutes of Health, USA

\section{*Correspondence:}

Raashid Ahmed Luqmani, NDORMS, Rheumatology Department, Nuffield Orthopaedic Centre, University of Oxford, Windmill Road, Oxford OX3 7LD, UK

email: raashid.luqmani@ndorms. ox.ac.uk
Anti-neutrophil cytoplasm antibodies (ANCA) are associated with small vessel vasculitides (AASV) affecting the lungs and kidneys. Structured clinical assessment using the Birmingham Vasculitis Activity Score and Vasculitis Damage Index should form the basis of a treatment plan and be used to document progress, including relapse. Severe disease with organ or life threatening manifestations needs cyclophosphamide or rituximab, plus high dose glucocorticoids, followed by lower dose steroid plus azathioprine, or methotrexate. Additional plasmapheresis is effective for very severe disease, reducing dialysis dependence from 60 to $40 \%$ in the first year, but with no effect on mortality or long-term renal function, probably due to established renal damage. In milder forms of ANCA-associated vasculitis, methotrexate, leflunomide, or mycophenolate mofetil are effective. Mortality depends on initial severity: $25 \%$ in patients with renal failure or severe lung hemorrhage; $6 \%$ for generalized non-life threatening AASV but rising to $30-40 \%$ at 5 years. Mortality from GPA is four times higher than the background population. Early deaths are due to active vasculitis and infection. Subsequent deaths are more often due to cardiovascular events, infection, and cancer. We need to improve the long-term outcome, by controlling disease activity but also preventing damage and drug toxicity. By contrast, in large vessel vasculitis where mortality is much less but morbidity potentially greater, such as giant cell arteritis (GCA) and Takayasu arteritis, therapeutic options are limited. High dose glucocorticoid results in significant toxicity in over $80 \%$. Advances in understanding the biology of the vasculitides are improving therapies. Novel, mechanism based therapies such as rituximab in AASV, mepolizumab in eosinophilic granulomatosis with polyangiitis, and tocilizumab in GCA, but the lack of reliable biomarkers remains a challenge to progress in these chronic relapsing diseases.

Keywords: vasculitis, cyclophosphamide, rituximab, ANCA, glucocorticoid, plasmapheresis, methotrexate, azathioprine

\section{INTRODUCTION}

The systemic vasculitides are a complex set of overlapping conditions whose natural history has been significantly modified by current therapies but continue to challenge patients and clinicians. We expect survival in over $90 \%$ (compared to over $90 \%$ mortality untreated) in the first year; about $70 \%$ with small vessel vasculitis survive up to 5 years, giving a mortality ratio of 2.6 (95\% CI 2.2-3.1) compared to background $(1,2)$.

In large vessel vasculitis, mortality is low (3) but morbidity is high. In giant cell arteritis (GCA), visual loss occurs in up to $35 \%$ (4). In Takayasu arteritis, ischemic claudication of limbs and great vessels can require surgical reconstruction (5).

Current therapies minimize systemic and local inflammation and can preserve organ function. Immunosuppressive agents are combined with supportive management, which includes: compensating for organ dysfunction (e.g., treating hypertension or providing dialysis); dealing with or preventing comorbidity, which might arise from treatment (e.g., infection, steroid related osteoporosis, or cataract); worsening of pre-existing comorbidity (e.g., worsening of ischemic heart disease or obesity); or development of new comorbidity.
We need to ensure that we identify what we are actually treating so that we tailor the choice of treatment at the right dose and at right time for each individual.

\section{WHAT ARE WE TREATING?}

Making an accurate diagnosis of the type of vasculitis is an important part of treatment choices. Figure 1 illustrates a typical plan of management for patients with vasculitis. There are no diagnostic criteria for the vasculitides; Chapel Hill Consensus Conference definitions are widely applied (6). Classification criteria for vasculitis are currently problematic (7) and research is underway to improve them (8). However, the diagnostic label is not enough. The patient's status should include assessment of disease severity and the context in which the disease occurs in individuals. Table 1 outlines the immunosuppressive therapies used to manage vasculitis.

The range of diseases encompassed includes small, medium, and large vessel vasculitis; small and medium vessel diseases are grouped together because the standard treatment approaches are very similar; however, they are starting to diversify as we develop more targeted agents. 


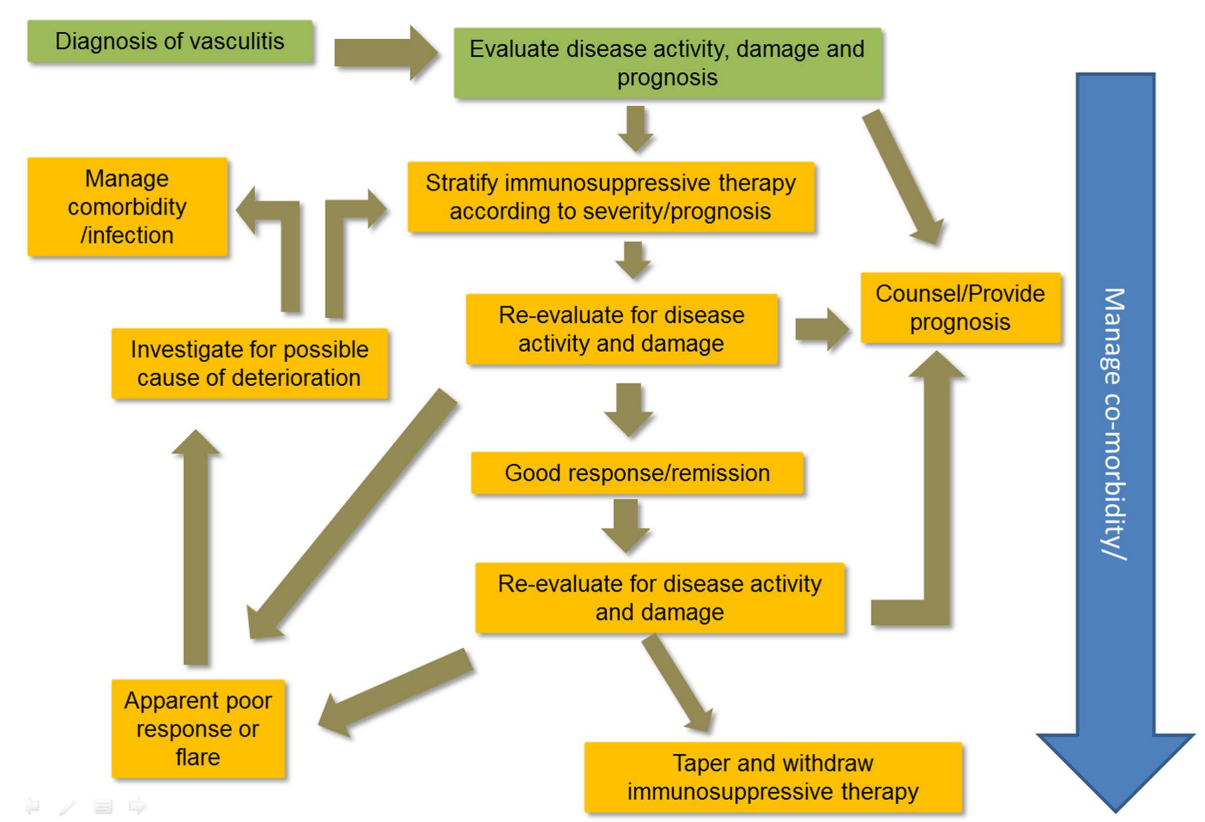

FIGURE 1 | Managing systemic vasculitis

For patients with a virus associated vasculitis, treatment of the virus is a prerequisite to controlling disease. Polyarteritis nodosa (PAN) related to hepatitis B (HBV-PAN), a typical form of PAN, is characterized by the absence of glomerulonephritis and the absence of anti-neutrophil cytoplasm antibodies (ANCA); relapses are rare, and never occur once viral replication has stopped and seroconversion has occurred (18). Eradication of hepatitis B is part of the management for HBV-PAN (18).Combining an anti-viral drug with plasmapheresis facilitates seroconversion and prevents the development of long-term hepatic complications of HBV. The incidence of HBV-PAN has decreased 10-fold as a result of improved blood safety and vaccination campaigns (19). In a study of 80 patients with HBV-PAN given anti-viral therapy plus immunosuppression, $5 \%$ relapsed and 30\% died compared with $14.3 \%$ relapses and $48.6 \%$ deaths among 35 patients treated with immunosuppression alone. Patients who seroconverted achieved complete remission and did not relapse.

Unfortunately, the eradication of hepatitis $\mathrm{C}$ has been more problematic; patients with cryoglobulinaemic vasculitis may continue to require ongoing anti-viral therapy. Combination antiviral therapy is more effective, as shown in a study of cryoglobulinaemic vasculitis; $69 \%$ of 23 cases treated with a combination of pegylated interferon alpha, ribavirin, and a protease inhibitor had achieved undetectable viral loads and a good clinical response in the majority including complete remission in 57\% (20).

In small vessel vasculitis associated with ANCA, these antibodies are intricately involved in the pathogenesis (21). The role of conventional immunosuppressive agents remains important. Cyclophosphamide is the gold standard for multi-system small vessel vasculitis $(22,23)$; for less aggressive forms of disease, there is a potential role for leflunomide (24), methotrexate (25) or in one small series, high dose intravenous azathioprine (13). Whilst small open label studies of tumor necrosis factor (TNF) inhibition have suggested benefit (26) in disease control and improvement in abnormal endothelial dysfunction, a large randomized placebo controlled trial of etanercept, a TNF receptor protein, has shown no benefit in patients with GPA; in fact these patients had an increased risk of malignancy, which may in part have related to the inclusion of patients previously exposed to large doses of cyclophosphamide (27). Direct targeting of B cell production of antibody is an effective therapy for many but not all patients (28-30).

For patients with large vessel vasculitis such as GCA or Takayasu arteritis, the primary treatment is glucocorticoids, but as we identify disease mechanisms, we should be able to use targeted therapies, avoiding the use of high doses of steroids, which result in very significant toxicity in over $80 \%$ (31).

\section{MECHANISM SPECIFIC VS. GLOBAL IMMUNOSUPPRESSION}

Immunosuppressive therapy results in global effects on the immune system, which can be both good and bad. Glucocorticoids produce a rapid improvement in all types of vasculitis by genomic effects on the cytosolic and more rapid non-genomic effects on the membrane bound glucocorticoid receptor (32), but these effects are short lived in small vessel vasculitis. By contrast, most patients experience significant steroid toxicity (over $80 \%$ for GCA) and this relates to the total steroid load (31). It is important to tailor the dose of steroids, often used together with an immunosuppressive agent (see Table 1), to minimize the harm, while still controlling disease.

Specific targeting of inflammatory immune mechanism in vasculitis is increasingly practical as we identify the molecular pathways that are primarily responsible for the disease. The role of complement in ANCA-associated vasculitis (33) has led to the 
Table 1 | Immunosuppressive therapies used to treat systemic vasculitis

\begin{tabular}{lllll}
\hline Drug & $\begin{array}{l}\text { Phase of } \\
\text { therapy }\end{array}$ & Dose & Indication/comments & $\begin{array}{l}\text { Common adverse } \\
\text { effects }\end{array}$
\end{tabular}

\section{NON-BIOLOGICAL IMMUNOSUPPRESSIVE THERAPIES USED TOTREAT SYSTEMIC VASCULITIS}

Glucocorticoids Induction and Varies but usually required at high initia maintenance dose $(0.75-1 \mathrm{mg} / \mathrm{kg} /$ day) tapering after 4 weeks with good disease control

Subsequent reduction of steroids is more rapid in the first 4-6 months (e.g., 5-15 $\mathrm{mg}$ per day reduction every $1-2$ weeks), then much slower (e.g., $1 \mathrm{mg}$ every $1-2$ months) for large vessel vasculitis; in small and medium vessel vasculitis, because the patient is usually also managed with another immunosuppressive agent,

glucocorticoid reduction protocols can be more aggressive

Pulse high dose intravenous methylprednisolone (500-1000 mg) may be indicated for organ or life threatening manifestations, but the evidence base for its use is poor

Cyclophosphamide Induction

Plasmapheresis Induction
Usually given intravenously as high dose intermittent pulses of $15 \mathrm{mg} / \mathrm{kg} /$ dose on 6-10 occasions, $2-3$ weeks apart. Oral pulse therapy is feasible and delivers higher level of active metabolites (due to first pass metabolism in liver to active compound

Continuous daily oral cyclophosphamide is also effective but the cumulative dose is much higher after 6 months compared to pulse therapy

Additional to conventional immunosuppression. No standard volume of exchange. A typical regimen would be to use between 7 and 10 exchanges ( $4 \mathrm{I}$ each) in first 10 days of induction therapy (9). It is not clear which method of plasmapheresis (centrifugation or filtration) is superior
For GCA and Takayasu arteritis, this may be the only immunosuppression given. For most other forms of systemic vasculitis, additional immunosuppressive agents are mandatory. Increasingly, we recognize the adverse effects of glucocorticoid therapy and the aim is to minimize their use

In small and medium vessel multi-system disease such as GPA, MPA, EGPA, and PAN, glucocorticoid therapy remains essential to the management, except for Kawasaki disease where it is rarely used

Most forms of small vessel ANCA vasculitis, some patients with PAN and some with large vessel vasculitis require cyclophosphamide

Rituximab is increasingly used as an alternative for patients with ANCA vasculitis who have failed cyclophosphamide or in whom cyclophosphamide is contraindicated

Evidence from one large randomized controlled trial suggests that additional plasmapheresis is renal sparing (10), but a follow up study of the same patient group suggested that the benefit did not last (11), suggesting that plasmapheresis may not be effective if used in patients with established kidney scarring

A smaller study of 32 patients with GPA with 5-year follow up showed that plasmapheresis plus cyclophosphamide and glucocorticoids followed by ciclosporin maintenance therapy was effective in patients with a creatinine of $>250 \mu \mathrm{mol} / \mathrm{l}$ at baseline (12)
Weight gain

Hyperglycemia

Mood swings

Easy bruising

Infection risk

Cataracts

Hypertension

Osteoporosis

Cushing's syndrome

Cytopenias

Nausea and vomiting

Diarrhea

Hair loss

Teratogenesis (avoid in

pregnancy)

Hemorrhagic cystitis

Long-term risk of infertility and malignancy (especially bladder carcinoma) relate to cumulative dose life-time exposure especially above $35 \mathrm{~g}$

Increased risk of sepsis especially if combined with cyclophosphamide

Potential risk of transmission of viral infection if using infected blood products 
Table 1 | Continued

\begin{tabular}{|c|c|c|c|c|}
\hline Drug & $\begin{array}{l}\text { Phase of } \\
\text { therapy }\end{array}$ & Dose & Indication/comments & $\begin{array}{l}\text { Common adverse } \\
\text { effects }\end{array}$ \\
\hline & & & $\begin{array}{l}\text { Avoid plasmapheresis shortly after } \\
\text { administration of other IV therapies } \\
\text { (otherwise they are removed) }\end{array}$ & \\
\hline Methotrexate & $\begin{array}{l}\text { Induction or } \\
\text { maintenance }\end{array}$ & $15-25$ mg/week oral or sc & $\begin{array}{l}\text { Can be used as effective induction } \\
\text { therapy for non-organ or non-life } \\
\text { threatening ANCA vasculitis. It provides } \\
\text { some additional benefit in control of } \\
\text { GCA. Avoid use in significant renal } \\
\text { impairment }\end{array}$ & $\begin{array}{l}\text { Nausea } \\
\text { Diarrhea } \\
\text { Mouth ulcers } \\
\text { Hair loss } \\
\text { Cytopenia } \\
\text { Liver dysfunction }\end{array}$ \\
\hline Leflunomide & $\begin{array}{l}\text { Induction or } \\
\text { maintenance }\end{array}$ & 10-40 mg/day & $\begin{array}{l}\text { This drug is used for inflammatory } \\
\text { arthritis but has shown benefit in } \\
\text { patients with localized GPA }\end{array}$ & $\begin{array}{l}\text { Nausea } \\
\text { Diarrhea } \\
\text { Mouth ulcers } \\
\text { Hair loss } \\
\text { Cytopenia } \\
\text { Liver dysfunction } \\
\text { Hypertension }\end{array}$ \\
\hline $\begin{array}{l}\text { Mycophenolate } \\
\text { mofetil }\end{array}$ & $\begin{array}{l}\text { Induction or } \\
\text { maintenance }\end{array}$ & 2-3 g per day & $\begin{array}{l}\text { Less effective than azathioprine as a } \\
\text { maintenance agent, nevertheless this } \\
\text { drug has a place in management of } \\
\text { ANCA vasculitis. As an induction agent it } \\
\text { appears to be as effective as } \\
\text { cyclophosphamide }\end{array}$ & $\begin{array}{l}\text { Nausea } \\
\text { Diarrhea } \\
\text { Mouth ulcers } \\
\text { Hair loss } \\
\text { Cytopenia } \\
\text { Liver dysfunction }\end{array}$ \\
\hline Co-trimoxazole & $\begin{array}{l}\text { Induction or } \\
\text { maintenance }\end{array}$ & $\begin{array}{l}960 \text { mg twice a day or } 960 \text { mg } 3 \times \text { per } \\
\text { week if used in combination with } \\
\text { methotrexate }\end{array}$ & $\begin{array}{l}\text { This simple antibiotic has } \\
\text { immunomodulatory effects in patients } \\
\text { with mild GPA and has been shown to } \\
\text { improve upper airways disease, usually } \\
\text { in combination with steroids. At the } \\
\text { reduced dose it can be used as } \\
\text { prophylaxis against pneumocystis } \\
\text { jirovecii in patients receiving other } \\
\text { immunosuppressive agents }\end{array}$ & $\begin{array}{l}\text { Beware allergy to } \\
\text { sulfonamide } \\
\text { Nausea } \\
\text { Diarrhea } \\
\text { Cytopenia (avoid full dose } \\
\text { if combined with } \\
\text { methotrexate) }\end{array}$ \\
\hline Azathioprine & $\begin{array}{l}\text { Induction } \\
\text { Maintenance }\end{array}$ & $\begin{array}{l}\text { Usually given as } 2 \mathrm{mg} / \mathrm{kg} / \text { day for } \\
\text { maintenance but there is one report of } \\
\text { using high dose intravenous pulse } \\
\text { therapy with } 1200 \mathrm{mg} \text { per month for } \\
6 \text { months in very resistant disease (13) }\end{array}$ & $\begin{array}{l}\text { This is a common maintenance agent, } \\
\text { following successful induction therapy } \\
\text { with either cyclophosphamide or } \\
\text { rituximab }\end{array}$ & $\begin{array}{l}\text { Nausea } \\
\text { Diarrhea } \\
\text { Mouth ulcers } \\
\text { Hair loss } \\
\text { Cytopenia } \\
\text { Liver dysfunction } \\
\text { Non-melanoma skin } \\
\text { tumors (advise sun } \\
\text { protection) }\end{array}$ \\
\hline Ciclosporin & Maintenance & $2-4 \mathrm{mg} / \mathrm{kg} /$ day in two divided doses & $\begin{array}{l}\text { Less commonly used than other agents, } \\
\text { largely due to its nephrotoxicity }\end{array}$ & $\begin{array}{l}\text { Nausea } \\
\text { Diarrhea } \\
\text { Gingival hyperplasia } \\
\text { Increased facial hair } \\
\text { Cytopenia } \\
\text { Renal dysfunction } \\
\text { Hypertension }\end{array}$ \\
\hline
\end{tabular}


Table 1 | Continued

\begin{tabular}{|c|c|c|c|c|}
\hline Drug & $\begin{array}{l}\text { Phase of } \\
\text { therapy }\end{array}$ & Dose & Indication/comments & $\begin{array}{l}\text { Common adverse } \\
\text { effects }\end{array}$ \\
\hline Gusperimus & Relapse & $\begin{array}{l}0.5 \mathrm{mg} / \mathrm{kg} / \text { day until neutropenia } \\
\text { develops or for up to } 21 \text { days repeated } \\
\text { every month for up to } 6 \text { months }\end{array}$ & $\begin{array}{l}\text { Unlicensed in Europe, this } \\
\text { immunomodulator therapy has been } \\
\text { effective in relapsing GPA (14) } \\
\text { Reversible and predictable neutropenia } \\
\text { Potential risk of sepsis }\end{array}$ & $\begin{array}{l}\text { Well tolerated but limited } \\
\text { information because of very } \\
\text { limited use }\end{array}$ \\
\hline \multicolumn{5}{|c|}{ BIOLOGICAL IMMUNOSUPPRESSIVE THERAPIES USEDTO TREAT SYSTEMIC VASCULITIS } \\
\hline $\begin{array}{l}\text { Intravenous } \\
\text { immunoglobulin } \\
\text { (IVIG) }\end{array}$ & Induction & $\begin{array}{l}2 \mathrm{~g} / \mathrm{kg} \text { single dose or divided over } \\
5 \text { days is typical therapy for Kawasaki } \\
\text { disease (15). These doses are much } \\
\text { higher than those used for } \\
\text { immunodeficiency }\end{array}$ & $\begin{array}{l}\text { Kawasaki disease is the main form of } \\
\text { vasculitis responding to IVIG, in } \\
\text { combination with high dose aspirin. } \\
\text { ANCA vasculitis will respond } \\
\text { temporarily, and this can be useful if } \\
\text { patients are also septic, because it is an } \\
\text { immunomodulating therapy. Check } \\
\text { serum IgA to avoid allergic reactions in } \\
\text { patients who are IgA deficient (because } \\
\text { there is usually some IgA } \\
\text { contamination). IVIG is prepared form } \\
\text { pooled human serum, typically from } \\
\text { thousands of donors. Viral screening of } \\
\text { IVIG is now highly effective (previous } \\
\text { IVIG therapy use has been associated } \\
\text { with hepatitis C transmission) }\end{array}$ & $\begin{array}{l}\text { Potential risk of transmission of } \\
\text { viral infection if using infected } \\
\text { blood products } \\
\text { Allergic reaction in patients } \\
\text { who are IgA deficient (due to } \\
\text { expected levels of small } \\
\text { amounts of IgA in the } \\
\text { preparation) } \\
\text { Headaches, flushing, fever, } \\
\text { chills, fatigue, nausea, and } \\
\text { diarrhea are transient reactions } \\
\text { during infusions }\end{array}$ \\
\hline Rituximab & $\begin{array}{l}\text { Induction or } \\
\text { maintenance }\end{array}$ & $\begin{array}{l}375 \mathrm{mg} / \mathrm{m}^{2} \text { every week for } 4 \text { weeks or } \\
1 \mathrm{~g} \times 214 \text { days apart are typical } \\
\text { induction regimens. Maintenance } \\
\text { therapy (typically } 1 \mathrm{~g} \text { single infusion) } \\
\text { can be given every } 4-6 \text { months } \\
\text { afterward }\end{array}$ & $\begin{array}{l}\text { Increasingly used in place of } \\
\text { cyclophosphamide as induction therapy } \\
\text { at initial presentation or during relapse } \\
\text { for ANCA vasculitis }\end{array}$ & $\begin{array}{l}\text { Infusion reactions neutropenia } \\
\text { hypogammaglobulinemia } \\
\text { Infections (including small risk } \\
\text { of progressive multifocal } \\
\text { leukoencephalopathy) } \\
\text { Potential for viral reactivation } \\
\text { (e.g., hepatitis B) } \\
\text { Development of other } \\
\text { autoimmune conditions }\end{array}$ \\
\hline Tocilizumab & Relapse & $\begin{array}{l}4 \mathrm{mg}-8 / \mathrm{kg} \text { per month intravenously or } \\
162 \mathrm{mg} \text { sc per fortnight if }<100 \mathrm{~kg} \text { or } \\
162 \mathrm{mg} \text { sc every week if } \geq 100 \mathrm{~kg}\end{array}$ & $\begin{array}{l}\text { Limited evidence for effectiveness in } \\
\text { large vessel vasculitis. A randomized } \\
\text { controlled trial in GCA is currently } \\
\text { underway (16) }\end{array}$ & $\begin{array}{l}\text { Infection risk } \\
\text { Potential masking of evidence } \\
\text { of sepsis (by down regulating } \\
\text { production of CRP) } \\
\text { Increased lipid levels } \\
\text { Neutropenia } \\
\text { Liver dysfunction } \\
\text { Infusion reactions are rare }\end{array}$ \\
\hline Mepolizumab & $\begin{array}{l}\text { Resistant } \\
\text { disease }\end{array}$ & $\begin{array}{l}\text { Two different regimens are being } \\
\text { explored: } \\
300 \text { mg sc every } 4 \text { weeks } \\
750 \text { mg iv every } 4 \text { weeks }\end{array}$ & $\begin{array}{l}\text { This interleukin five inhibitor is effective } \\
\text { in hypereosinophilic states and the iv } \\
\text { regimen has been shown to control } \\
\text { resistant cases of EGPA (17). A } \\
\text { randomized controlled trial using the sc } \\
\text { regimen is underway (http://clinicaltrials. } \\
\text { gov/show/NCT02020889) }\end{array}$ & $\begin{array}{l}\text { Limited evidence available only } \\
\text { to date } \\
\text { No increase in toxicity } \\
\text { compared to placebo (e.g., } \\
\text { fatigue, nausea) }\end{array}$ \\
\hline
\end{tabular}

Patients are typically given intense induction therapy followed by maintenance. Most patients will require additional therapy to manage comorbidity and limit drug toxicity. Induction therapies can be repeated for relapse; however, it may be necessary to change the type of induction due to toxicity or poor initial response. 
development of targeted therapy against complement 5A (C5a), which is currently being tested in clinical trials ${ }^{1}$. The involvement by ANCA itself has led to development of specific B cell ablation therapy using rituximab and now belimumab ${ }^{2}$. As newer understanding of disease mechanisms is revealed then more targets for therapy will be identified or at least we will have better recognition of how we are affecting the underlying pathways with existing therapies.

\section{CAN WE INDUCE REMISSION?}

The aim of managing the patients with vasculitis is to induce remission, which should be possible in the majority. However, this is a clinical remission not a cure and the majority of patients will relapse. We need to deliver treatment according to need without exposing patients to unnecessary risk whilst ensuring the maximum benefit. Conventional measurements of clinical remission are defined using disease activity scores, which are preferred to any current serological marker for small vessel and medium vessel vasculitis. In over $90 \%$ of patients with small vessel vasculitis, remission should be achieved by 6 months (22) using standard induction therapy. Further serial evaluation is important in order to detect and treat relapses.

By contrast, in large vessel vasculitis, the induction of remission is less easily documented. All the clinical symptoms and signs disappear rapidly with steroid treatment; by contrast, it is not so clear that we have adequately controlled disease at a sub-clinical level. Imaging is emerging as an effective technology to define disease activity. Unfortunately, it is expensive and can involve significant radiation exposure. The best imaging technique available is $18 \mathrm{flu}-$ orodeoxyglucose positron emission tomography with co-localized computerized tomography (FDG PET CT) to identify areas of abnormal glucose uptake. However, this involves exposure to an average of $14.4 \mathrm{mSv}$ for females and $11.8 \mathrm{mSv}$ for male patients (34) per scan. Nevertheless, it is important to quantify the presence of sub-clinical disease to find ways of preventing end stage ischemic complications or other vascular events such as thrombosis, dissection, and aneurysm. Non-invasive imaging protocols using magnetic resonance scans or ultrasound are being developed as ways of measuring change in disease state $(35,36)$.

\section{HOW DO WE MEASURE REMISSION?}

Serological measurements of disease activity are not reliable in systemic vasculitis (37). ANCA testing is very useful for diagnosis, but for subsequent follow up, levels can vary independently of future disease activity (38).

The Birmingham Vasculitis Activity Score (BVAS) is the most effective validated tool to document disease activity; it can be used as to define remission, response to therapy and flare $(37,39,40)$. The BVAS consists of a list of typical features of active systemic vasculitis related to each body system; each item is recorded as present only if it is judged to be due to active vasculitis. This is semi-subjective because items are derived from the patient history and physical examination and cannot always be confirmed

\footnotetext{
${ }^{1} \mathrm{http} / /$ clinicaltrials.gov/show/NCT01275287;

http://www.controlled-trials.com/ISRCTN53663626

${ }^{2} \mathrm{http}: / /$ clinicaltrials.gov/show/NCT01663623
}

with more objective testing. However, the BVAS is valid, reliable, and widely used in clinical trials in vasculitis to define the responsiveness to various agents including cyclophosphamide, methotrexate, mycophenolate, intravenous immunoglobulin, and rituximab. It is a valuable tool for the clinicians and strongly recommended as a routine part of disease management in small and medium vessel vasculitis $(40,41)$. Other versions of BVAS have been validated for use in individual forms of vasculitis, such as the BVAS/Wegener's granulomatosis, specifically for patients with GPA (42).

The Vasculitis Damage Index (VDI) is used to assess the outcome of vasculitis, by documenting the occurrence of damage as a result of having a diagnosis of vasculitis $(43,44)$. VDI is recommended as a cumulative measure to define the effectiveness of therapy (by limiting or preventing the accumulation of scarring). The VDI is strongly related to mortality. The presence of VDI levels of at least five points on a scale of 0-64 items (which occurs in about a third of patients (45) when measured 6 months from diagnosis) is associated with a much higher future mortality (approximately sixfold higher) than patients with less than five items of damage (46) 6 months from diagnosis.

\section{WHAT DRUGS SHOULD WE USE?}

Each patient's management should be based on their diagnosis and clinical state. Control of active vasculitis may be achieved using a range of therapies, depending on how rapidly and aggressively the treatment is required. The decision should be based on evidence, but interpreted for the individual to minimize harm, taking into account existing or likely co-morbidities. Some treatment protocols allow for this. For example, there are dose reductions for the dose of cyclophosphamide in older persons, those with renal impairment or with prior significant neutropenia (23).

The treatment protocol may need to be amended if unexpected changes occur in clinical status, either as a result of toxicity or if patients fail to respond to standard agents. Therapy should be withheld until inter-current infection is treated, or escalated in cases with poor initial response. Fundamental to these decisions is the regular careful clinical evaluation of patients to detect these changes. Table 1 summarizes the immunosuppressive agents commonly used as well as describing potential future therapies under investigation.

\section{IMMUNOSUPPRESSIVE THERAPIES}

The main drug used is cyclophosphamide, cyclic nitrogen mustard, phosphamide ester, first used as a chemotherapeutic agent in the 1950s (47). Cyclophosphamide is a cytotoxic alkylating agent capable of killing B cells and T-cells. It is life-saving in patients with small and medium vessel vasculitis and is considered the drug of choice for multi organ disease (22).

However, the toxicity has been considerable, when used as continuous daily oral therapy for up to 2.7 years, providing over $100 \mathrm{~g}$ life-time exposure in some patients $(48,49)$, mainly due to its predicted cytotoxic effects on rapidly dividing normal cells. It can cause reversible nausea, vomiting, diarrhea, and hair loss; permanent infertility and malignancy occur with increasing cumulative doses, with an incidence of $5 \%$ at 10 years and $16 \%$ after 15 years (50). There is no absolute cut-off dose to avoid toxicity, 
but the recent British Society for Rheumatology guidelines for management of ANCA-associated vasculitis recommend restricting total exposure to $<25 \mathrm{~g}$ (41). Current cyclophosphamide protocols use a much lower cumulative dose and the bladder cancer incidence is not increased (51). However, in a study of male fertility risk in patients given cyclophosphamide for sarcoma (52), a total dose of $>7.5 \mathrm{~g} / \mathrm{m}^{2}$ was associated with only a $10 \%$ chance of recovery of spermatogenesis compared to $70 \%$ for those given less than this dose. The use of short courses of high dose intravenous cyclophosphamide is likely to be safer than continuous daily oral therapy (53), chiefly due to the fact that the cumulative dose is typically $30-50 \%$ less.

Cyclophosphamide is effective in reducing the mortality in ANCA-associated vasculitis $(22,23)$. It can be given either as a pulse intravenous high dose therapy $15 \mathrm{mg} / \mathrm{kg}$ every $2-3$ weeks on $6-10$ occasions or as a continuous daily oral therapy at $2 \mathrm{mg} / \mathrm{kg} /$ day (54). The latter results in much higher cumulative dose of drug over 6 months period and there is evidence of equivalent of these two regimens; although the use of pulse cyclophosphamide is associated with a higher relapse rate (23). For less aggressive forms of vasculitis, there is a potential role for leflunomide (24), methotrexate $(23,25,55)$ or in one small series, high dose intravenous azathioprine (13), and mycophenolate mofetil (56). These agents are usually less toxic but also less effective than cyclophosphamide.

For patients with large vessel vasculitis such as GCA or Takayasu arteritis, the primary treatment is to suppress systemic inflammation with glucocorticoid therapy in order to prevent significant vascular complications (such as loss of sight in GCA or aortic aneurysm formation or stenosis or occlusion of peripheral arteries in Takayasu arteritis. With better understanding of disease mechanisms, we might be able to use targeted therapies, perhaps even avoiding the use of steroids, which otherwise carry very significant risk of toxicity in over $80 \%$ (31).

There is some evidence for the effectiveness of TNF inhibition in small vessel vasculitis (26), but concerns about long-term toxicity (27).In Takayasu arteritis (35), studies show improvement but are limited to small numbers and there are no randomized controlled trials. This is partly due to the problem of not having adequate end points to demonstrate a potential treatment effect as well as due to the rarity of the condition (57). Direct targeting of B cells is an effective therapy for many patients; the response (64\% in complete remission by 6 months) is similar to that achieved with cyclophosphamide (53\% in complete remission by 6 months) for a group of 197 patients with new or relapsing ANCA-associated vasculitis; limited evidence suggests that in 102 patients with relapsing disease previously responding to cyclophosphamide, rituximab was more effective than cyclophosphamide (67 vs. $42 \%$ in complete remission respectively, $p=0.01)(28-30)$.

For any form of B cell depletion therapy, it is logical to assume that reconstitution of $\mathrm{B}$ cells after the end of treatment will lead to recurrence (58), although this is disputed, with at least one study demonstrating that disease relapse was independent of B cell numbers (59). Nevertheless, maintenance rituximab substantially reduces the risk of recurrence of disease from 73 to $12 \%$ after 2 years follow up in retrospective cohort data (60). Another retrospective observational study of 89 patients treated with rituximab for ANCA-associated vasculitis (60) suggests that there was additional protection against future relapse by using maintenance azathioprine, methotrexate, or mycophenolate mofetil compared to no additional immunosuppressive treatment [the hazard ratio for relapse was 0.53 (95\% CI 0.29-0.97) if a maintenance drug was given].

\section{DISCUSSION}

The state of the art for therapy in vasculitis has improved, but remains unsatisfactory until we can completely control or cure the disease. We can prevent early mortality in multi-system vasculitis and have reduced the immediate effects of active vasculitis on organ function. However, our aim is to further improve the likelihood of survival and also the quality of life of those who survive, ensuring that we minimize disease activity and damage, drug toxicity, and impairment of quality of life.

With better understanding of the pathogenesis of vasculitis, we can target therapy against specific disease mechanisms. Examples of these are rituximab in ANCA-associated vasculitis; mepolizumab in eosinophilic granulomatosis with polyangiitis; complement 5a inhibition in ANCA vasculitis; and potentially Interleukin-6 (IL-6) inhibition with tocilizumab in large vessel vasculitis.

We are helped in our management of the disease by earlier diagnosis, so that treatment can be initiated before organ damage is established in most cases. Whilst the ANCA test is overused $(61,62)$, it has helped in earlier identification of patients with systemic vasculitis (63). Greater awareness of vasculitis as a cause of unexplained medical illness is leading to better case recognition. Imaging of arteries in large vessel vasculitis may become established as an early diagnostic test (64), which might change our current management approach.

Better management of comorbidity, particularly management of sepsis, control of hypertension, or management of renal failure have changed the outcome and potentially allowed more aggressive immunosuppression to be successful. However, in first 12 months after diagnosis of ANCA vasculitis, episodes of acute sepsis are now responsible for more deaths than vasculitis itself (49).

The role of glucocorticoids in vasculitis is being challenged. Whereas, previously they have been used at high doses for prolonged periods, we recognize their harm, coupled by the benefit from more specific therapy. We should see substantial reduction in toxicity in the coming decade, as we use lower doses or even steroid free regimens to control vasculitis.

Whilst the twentieth century has been dominated by use of the therapies for vasculitis designed to treat other conditions [e.g., cancer and rheumatoid arthritis $(23,65,66)]$, drugs are now been designed specifically for vasculitis. We should see significant benefits for our patients, but we need to ensure that we measure their impact (for good and for harm). In the absence of reliable circulating biomarkers we need to use structured clinical assessment to document change in disease state in response to therapy. Development of effective, prognostic biomarkers for vasculitis would allow therapy to be targeted to disease mechanisms, tempered by safety assessments to prevent untoward harm. 


\section{ACKNOWLEDGMENTS}

Jana Vaskova for administrative support. NIHR Biomedical Research Unit in Musculoskeletal Disease at Oxford University Hospitals NHS Trust and the University of Oxford for support.

\section{REFERENCES}

1. Flossmann O, Berden A, De Groot K, Hagen C, Harper L, Heijl C, et al. Longterm patient survival in ANCA-associated vasculitis. Ann Rheum Dis (2011) 70:488-94. doi:10.1136/ard.2010.137778

2. Walton EW. Giant-cell granuloma of the respiratory tract (Wegener's granulomatosis). Br Med J (1958) 2:265-70. doi:10.1136/bmj.2.5091.265

3. Phillip R, Luqmani R. Mortality in systemic vasculitis: a systematic review. Clin Exp Rheumatol (2008) 26(5 Suppl 51):S94-104.

4. Souza AW, Okamoto KY, Abrantes F, Schau B, Bacchiega AB, Shinjo SK. Giant cell arteritis: a multicenter observational study in Brazil. Clinics (Sao Paulo) (2013) 68(3):317-22. doi:10.6061/clinics/2013(03)OA06

5. Saadoun D, Lambert M, Mirault T, Resche-Rigon M, Koskas F, Cluzel P, et al. Retrospective analysis of surgery versus endovascular intervention in Takayasu arteritis: a multicenter experience. Circulation (2012) 125(6):813-9. doi:10.1161/CIRCULATIONAHA.111.058032

6. Jennette JC, Falk RJ, Bacon PA, Basu N, Cid MC, Ferrario F, et al. 2012 revised international Chapel Hill consensus conference nomenclature of vasculitides. Arthritis Rheum (2013) 65(1):1-11. doi:10.1002/art.37715

7. Basu N, Watts R, Bajema I, Baslund B, Bley T, Boers M, et al. EULAR points to consider in the development of classification and diagnostic criteria in systemic vasculitis. Ann Rheum Dis (2010) 69(10):1744-50. doi:10.1136/ard.2009. 119032

8. Craven A, Robson J, Ponte C, Grayson PC, Suppiah R, Judge A, et al ACR/EULAR-endorsed study to develop diagnostic and classification criteria for vasculitis (DCVAS). Clin Exp Nephrol (2013) 17(5):619-21. doi:10.1007/ s10157-013-0854-0

9. De Joode AA, Sanders JS, Smid WM, Stegeman CA. Plasmapheresis rescue therapy in progressive systemic ANCA-associated vasculitis: single-center results of stepwise escalation of immunosuppression. J Clin Apher (2014). doi:10.1002/jca.21318

10. Jayne DR, Gaskin G, Rasmussen N, Abramowicz D, Ferrario F, Guillevin L, et al. Randomized trial of plasma exchange or high-dosage methylprednisolone as adjunctive therapy for severe renal vasculitis. J Am Soc Nephrol (2007) 18(7):2180-8. doi:10.1681/ASN.2007010090

11. Walsh M, Casian A, Flossmann O, Westman K, Höglund P, Pusey C, et al. Longterm follow-up of patients with severe ANCA-associated vasculitis comparing plasma exchange to intravenous methylprednisolone treatment is unclear. Kidney Int (2013) 84(2):397-402. doi:10.1038/ki.2013.131

12. Szpirt WM, Heaf JG, Petersen J. Plasma exchange for induction and cyclosporine A for maintenance of remission in Wegener's granulomatosis - a clinical randomized controlled trial. Nephrol Dial Transplant (2011) 26(1):206-13. doi:10.1093/ndt/gfq360

13. Aries PM, Hellmich B, Reinhold-Keller E, Gross WL. High-dose intravenous azathioprine pulse treatment in refractory Wegener's granulomatosis. Rheumatology (Oxford) (2004) 43(10):1307-8. doi:10.1093/rheumatology/ keh300

14. Flossmann O, Baslund B, Bruchfeld A, Tervaert JW, Hall C, Heinzel P, et al Deoxyspergualin in relapsing and refractory Wegener's granulomatosis. Ann Rheum Dis (2009) 68(7):1125-30. doi:10.1136/ard.2008.092429

15. Newburger JW, Takahashi M, Burns JC, Beiser AS, Chung KJ, Duffy CE, et al. The treatment of Kawasaki syndrome with intravenous gamma globulin. N Engl J Med (1986) 315(6):341-7. doi:10.1056/NEJM198608073150601

16. Unizony S, Arias-Urdaneta L, Miloslavsky E, Arvikar S, Khosroshahi A, Keroack $\mathrm{B}$, et al. Tocilizumab for the treatment of large-vessel vasculitis (giant cell arteritis, Takayasu arteritis) and polymyalgia rheumatica. Arthritis Care Res (Hoboken) (2012) 64(11):1720-9. doi:10.1002/acr.21750

17. Moosig F, Gross WL, Herrmann K, Bremer JP, Hellmich B. Targeting interleukin5 in refractory and relapsing Churg-Strauss syndrome. Ann Intern Med (2011) 155(5):341-3. doi:10.7326/0003-4819-155-5-201109060-00026

18. Guillevin L, Mahr A, Callard P, Godmer P, Pagnoux C, Leray E, et al. Hepatitis $B$ virus-associated polyarteritis nodosa: clinical characteristics, outcome, and impact of treatment in 115 patients. Medicine (Baltimore) (2005) 84(5):313-22. doi:10.1097/01.md.0000180792.80212.5e
19. Sagnelli E, Sagnelli C, Pisaturo M, Macera M, Coppola N. Epidemiology of acute and chronic hepatitis B and delta over the last 5 decades in Italy. World J Gastroenterol (2014) 20(24):7635-43. doi:10.3748/wjg.v20.i24.7635

20. Saadoun D, Resche Rigon M, Thibault V, Longuet M, Pol S, Blanc F, et al. PegIFN $\alpha /$ ribavirin/protease inhibitor combination in hepatitis $C$ virus associated mixed cryoglobulinemia vasculitis: results at week 24. Ann Rheum Dis (2014) 73(5):831-7. doi:10.1136/annrheumdis-2012-202770

21. Jennette JC, Falk RJ. Pathogenesis of antineutrophil cytoplasmic autoantibodymediated disease. Nat Rev Rheumatol (2014) 10(8):463-73. doi:10.1038/ nrrheum.2014.103

22. Jayne D, Rasmussen N, Andrassy K, Bacon P, Tervaert JW, Dadoniené J, et al. A randomized trial of maintenance therapy for vasculitis associated with antineutrophil cytoplasmic autoantibodies. N Engl J Med (2003) 349(1):36-44. doi:10.1056/NEJMoa020286

23. De Groot K, Harper L, Jayne DR, Flores Suarez LF, Gregorini G, Gross WL, et al. EUVAS (European vasculitis study group). Pulse versus daily oral cyclophosphamide for induction of remission in antineutrophil cytoplasmic antibodyassociated vasculitis: a randomized trial. Ann Intern Med (2009) 150(10):670-80. doi:10.7326/0003-4819-150-10-200905190-00004

24. Metzler C, Miehle N, Manger K, Iking-Konert C, De Groot K, Hellmich B, et al. German network of rheumatic diseases. elevated relapse rate under oral methotrexate versus leflunomide for maintenance of remission in Wegener's granulomatosis. Rheumatology (Oxford) (2007) 46(7):1087-91. doi:10.1093/ rheumatology/kem029

25. De Groot K, Rasmussen N, Bacon PA, Tervaert JW, Feighery C, Gregorini $\mathrm{G}$, et al. Randomized trial of cyclophosphamide versus methotrexate for induction of remission in early systemic antineutrophil cytoplasmic antibodyassociated vasculitis. Arthritis Rheum (2005) 52(8):2461-9. doi:10.1002/art. 21142

26. Booth AD, Jayne DR, Kharbanda RK, McEniery CM, Mackenzie IS, Brown J, et al. Infliximab improves endothelial dysfunction in systemic vasculitis: a model of vascular inflammation. Circulation (2004) 109(14):1718-23. doi:10.1161/01. CIR.0000124720.18538.DD

27. The Wegener's Granulomatosis Etanercept Trial Research Group. Limited versus severe Wegener's granulomatosis: baseline data on patients in the Wegener's granulomatosis etanercept trial. Arthritis Rheum (2003) 48:2299-309. doi:10. 1002/art.11075

28. Stone JH, Merkel PA, Spiera R, Seo P, Langford CA, Hoffman GS, et al. Rituximab versus cyclophosphamide for ANCA-associated vasculitis. $N$ Engl J Med (2010) 363(3):221-32. doi:10.1056/NEJMoa0909905

29. Jones RB, Tervaert JW, Hauser T, Luqmani R, Morgan MD, Peh CA, et al. European vasculitis study group rituximab versus cyclophosphamide in ANCAassociated renal vasculitis. N Engl J Med (2010) 363(3):211-20. doi:10.1056/ NEJMoa0909169

30. Specks U, Merkel PA, Seo P, Spiera R, Langford CA, Hoffman GS, et al. Efficacy of remission-induction regimens for ANCA-associated vasculitis. $\mathrm{N} \mathrm{Engl} \mathrm{J} \mathrm{Med}$ (2013) 369(5):417-27. doi:10.1056/NEJMoa1213277

31. Proven A, Gabriel SE, Orces C, O'Fallon WM, Hunder GG. Glucocorticoid therapy in giant cell arteritis: duration and adverse outcomes. Arthritis Rheum (2003) 49(5):703-8. doi:10.1002/art.11388

32. Strehl C, Buttgereit F. Unraveling the functions of the membrane-bound glucocorticoid receptors: first clues on origin and functional activity. Ann N Y Acad Sci (2014) 1318:1-6. doi:10.1111/nyas.12364

33. Xiao H, Schreiber A, Heeringa P, Falk RJ, Jennette JC. Alternative complement pathway in the pathogenesis of disease mediated by anti-neutrophil cytoplasmic autoantibodies. Am J Pathol (2007) 170(1):52-64. doi:10.2353/ajpath.2007. 060573

34. Kaushik A, Jaimini A, Tripathi M, D’Souza M, Sharma R, Mishra AK, et al. Estimation of patient dose in (18)F-FDG and (18)F-FDOPA PET/CT examinations. J Cancer Res Ther (2013) 9(3):477-83. doi:10.4103/0973-1482. 119354

35. Youngstein T, Peters JE, Hamdulay SS, Mewar D, Price-Forbes A, Lloyd M, et al. Serial analysis of clinical and imaging indices reveals prolonged efficacy of TNF$\alpha$ and IL- 6 receptor targeted therapies in refractory Takayasu arteritis. Clin Exp Rheumatol (2014) 32(2 Suppl 82):S11-8.

36. Muto G, Yamashita H, Takahashi Y, Miyata Y, Morooka M, Minamimoto R, et al. Large vessel vasculitis in elderly patients: early diagnosis and steroidresponse evaluation with FDG-PET/CT and contrast-enhanced CT. Rheumatol Int (2014). doi:10.1007/s00296-014-2985-3 
37. Luqmani RA, Bacon PA, Moots RJ, Janssen BA, Pall A, Emery P, et al. Birmingham vasculitis activity score (BVAS) in systemic necrotizing vasculitis. QJM (1994) 87(11):671-8.

38. Tomasson G, Grayson PC, Mahr AD, Lavalley M, Merkel PA. Value of ANCA measurements during remission to predict a relapse of ANCA-associated vasculitis - a meta-analysis. Rheumatology (Oxford) (2012) 51(1):100-9. doi:10. 1093/rheumatology/ker280

39. Mukhtyar C, Lee R, Brown D, Carruthers D, Dasgupta B, Dubey S, et al. Modification and validation of the Birmingham vasculitis activity score (version 3). Ann Rheum Dis (2009) 68(12):1827-32. doi:10.1136/ard.2008. 101279

40. Mukhtyar C, Guillevin L, Cid MC, Dasgupta B, De Groot K, Gross W, et al. European vasculitis study group. EULAR recommendations for the management of primary small and medium vessel vasculitis. Ann Rheum Dis (2009) 68(3):310-7. doi:10.1136/ard.2008.088096

41. Ntatsaki E, Carruthers D, Chakravarty K, D'Cruz D, Harper L, Jayne D, et al. Guidelines and audit working group. BSR and BHPR guideline for the management of adults with ANCA-associated vasculitis. Rheumatology (Oxford) (2014). doi:10.1093/rheumatology/ket445

42. Stone JH, Hoffman GS, Merkel PA, Min YI, Uhlfelder ML, Hellmann DB, et al. International network for the study of the systemic vasculitides (INSSYS). A disease-specific activity index for Wegener's granulomatosis: modification of the Birmingham vasculitis activity score. Arthritis Rheum (2001) 44(4):912-20. doi:10.1002/1529-0131(200104)44:4<912::AIDANR148>3.0.CO;2-5

43. Exley AR, Bacon PA, Luqmani RA, Kitas GD, Gordon C, Savage CO, et al. Development and initial validation of the vasculitis Damage Index for the standardized clinical assessment of damage in the systemic vasculitides. Arthritis Rheum (1997) 40(2):371-80. doi:10.1002/art.1780400222

44. Suppiah R, Flossman O, Mukhtyar C, Alberici F, Baslund B, Brown D, et al. Measurement of damage in systemic vasculitis: a comparison of the vasculitis damage index with the combined damage assessment index. Ann Rheum Dis (2011) 70(1):80-5. doi:10.1136/ard.2009.122952

45. Robson J, Doll H, Suppiah R, Flossmann O, Harper L, Höglund P, et al. Damage in the anca-associated vasculitides: long-term data from the European vasculitis study group (EUVAS) therapeutic trials. Ann Rheum Dis (2013). doi:10.1136/annrheumdis-2013-203927

46. Exley AR, Carruthers DM, Luqmani RA, Kitas GD, Gordon C, Janssen BA, et al. Damage occurs early in systemic vasculitis and is an index of outcome. QJM (1997) 90:391-9. doi:10.1093/qjmed/90.6.391

47. Arnold H, Bourseaux F, Brock N. Chemotherapeutic action of a cyclic nitrogen mustard phosphamide ester (B 518-ASTA) in experimental tumours of the rat. Nature (1958) 181(4613):931. doi:10.1038/181931a0

48. Stillwell TJ, Benson RC Jr, DeRemee RA, McDonald TJ, Weiland LH Cyclophosphamide-induced bladder toxicity in Wegener's granulomatosis. Arthritis Rheum (1988) 31(4):465-70. doi:10.1002/art.1780310402

49. Little MA, Nightingale P, Verburgh CA, Hauser T, De Groot K, Savage C, et al Early mortality in systemic vasculitis: relative contribution of adverse events and active vasculitis. Ann Rheum Dis (2010) 69(6):1036-43. doi:10.1136/ard.2009. 109389

50. Talar-Williams C, Hijazi YM, Walther MM, Linehan WM, Hallahan CW, Lubensky I, et al. Cyclophosphamide-induced cystitis and bladder cancer in patients with Wegener granulomatosis. Ann Intern Med (1996) 124(5):477-8. doi:10.7326/0003-4819-124-5-199603010-00003

51. Heijl C, Harper L, Flossmann O, Stücker I, Scott DG, Watts RA, et al. Incidence of malignancy in patients treated for antineutrophil cytoplasm antibody-associated vasculitis: follow-up data from European vasculitis study group clinical trials. Ann Rheum Dis (2011) 70(8):1415-21. doi:10.1136/ard.2010.145250

52. Meistrich ML, Wilson G, Brown BW, Da Cunha MF, Lipshultz LI. Impact of cyclophosphamide on long-term reduction in sperm count in men treated with combination chemotherapy for Ewing and soft tissue sarcomas. Cancer (1992) 70(11):2703-12. doi:10.1002/1097-0142(19921201)70:11<2703::AIDCNCR2820701123>3.0.CO;2-X

53. Monach PA, Arnold LM, Merkel PA. Incidence and prevention of bladder toxicity from cyclophosphamide in the treatment of rheumatic diseases: a data-driven review. Arthritis Rheum (2010) 62:921. doi:10.1002/art.27674
54. Harper L, Morgan MD, Walsh M, Hoglund P, Westman K, Flossmann O, et al. Pulse versus daily oral cyclophosphamide for induction of remission in ANCA-associated vasculitis: long-term follow-up. Ann Rheum Dis (2012) 71(6):955-60. doi:10.1136/annrheumdis-2011-200477

55. Faurschou M, Westman K, Rasmussen N, de Groot K, Flossmann O, Höglund $\mathrm{P}$, et al. Brief report: long-term outcome of a randomized clinical trial comparing methotrexate to cyclophosphamide for remission induction in early systemic antineutrophil cytoplasmic antibody-associated vasculitis. Arthritis Rheum (2012) 64:34727. doi:10.1002/art.34547

56. Hiemstra TF, Walsh M, Mahr A, Savage CO, De Groot K, Harper L, et al. Mycophenolate mofetil vs azathioprine for remission maintenance in antineutrophil cytoplasmic antibody-associated vasculitis: a randomized controlled trial. JAMA (2010) 304(21):2381-8. doi:10.1001/jama.2010.1658

57. Direskeneli H, Aydin SZ, Kermani TA, Matteson EL, Boers M, Herlyn K, et al. Development of outcome measures for large-vessel vasculitis for use in clinical trials: opportunities, challenges, and research agenda. J Rheumatol (2011) 38(7):1471-9. doi:10.3899/jrheum.110275

58. Cartin-Ceba R, Golbin JM, Keogh KA, Peikert T, Sánchez-Menéndez M, Ytterberg SR, et al. Rituximab for remission induction and maintenance in refractory granulomatosis with polyangiitis (Wegener's): ten-year experience at a single center. Arthritis Rheum (2012) 64(11):3770-8. doi:10.1002/art.34584

59. Smith RM, Jones RB, Guerry MJ, Laurino S, Catapano F, Chaudhry A, et al Rituximab for remission maintenance in relapsing antineutrophil cytoplasmic antibody-associated vasculitis. Arthritis Rheum (2012) 64(11):3760-9. doi:10.1002/art.34583

60. Azar L, Springer J, Langford CA, Hoffman GS. Rituximab with or without a conventional maintenance agent in relapsing granulomatosis with polyangiitis: a retrospective single-center study. Arthritis Rheumatol (2014) 66(10):2862-70. doi:10.1002/art.38744

61. McLaren JS, Stimson RH, McRorie ER, Coia JE, Luqmani RA. The diagnostic value of anti-neutrophil cytoplasmic antibody testing in a routine clinical setting. QJM (2001) 94(11):615-21. doi:10.1093/qjmed/94.11.615

62. Arnold DF, Timms A, Luqmani R, Misbah SA. Does a gating policy for ANCA overlook patients with ANCA associated vasculitis? An audit of 263 patients. J Clin Pathol (2010) 63(8):678-80. doi:10.1136/jcp.2009.072504

63. Edmunds M, Andrews M, Campbell A, Walls J, Feehally J. Systemic vasculitis in the 1980 s - is there an increasing incidence of Wegener's granulomatosis and microscopic polyarteritis? J R Coll Physicians Lond (1990) 24(4):284-8.

64. Schmidt WA, Kraft HE, Völker L, Vorpahl K, Gromnica-Ihle EJ. Colour Doppler sonography to diagnose temporal arteritis. Lancet (1995) 345(8953):866. doi: 10.1016/S0140-6736(95)93005-1

65. Walsh M, Chaudhry A, Jayne D. Long-term follow-up of relapsing/refractory anti-neutrophil cytoplasm antibody associated vasculitis treated with the lymphocyte depleting antibody alemtuzumab (CAMPATH-1H). Ann Rheum Dis (2008) 67(9):1322-7. doi:10.1136/ard.2007.081661

66. Langford CA, Monach PA, Specks U, Seo P, Cuthbertson D, McAlear CA, et al. Vasculitis clinical research consortium. An open-label trial of abatacept (CTLA4IG) in non-severe relapsing granulomatosis with polyangiitis (Wegener's). Ann Rheum Dis (2014) 73(7):1376-9. doi:10.1136/annrheumdis-2013-204164

Conflict of Interest Statement: The author declares that the research was conducted in the absence of any commercial or financial relationships that could be construed as a potential conflict of interest.

Received: 25 July 2014; accepted: 13 September 2014; published online: 13 October 2014.

Citation: Luqmani RA (2014) State of the art in the treatment of systemic vasculitides. Front. Immunol. 5:471. doi: 10.3389/fimmu.2014.00471

This article was submitted to Inflammation, a section of the journal Frontiers in Immunology.

Copyright (c) 2014 Luqmani. This is an open-access article distributed under the terms of the Creative Commons Attribution License (CC BY). The use, distribution or reproduction in other forums is permitted, provided the original author(s) or licensor are credited and that the original publication in this journal is cited, in accordance with accepted academic practice. No use, distribution or reproduction is permitted which does not comply with these terms. 